\title{
Herpetofaunal responses to brush management with herbi- cide and fire
}

\author{
BOB JONES, STANLEY F. FOX, DAVID M. LESLIE, JR., DAVID M. ENGLE, AND ROBERT L. LOCHMILLER
}

Authors are former graduate teaching assistant and professor, Department of Zoology; unit leader, U.S. Geological Survey, Biological Resources Division, Oklahoma Cooperative Fish and Wildlife Research Unit; professor, Department of Plant and Soil Sciences; and professor, Department of Zoology, Oklahoma State University, Stillwater, Okla. 74078. Reprint requests should be sent to S. F. Fox.

Abstract

We examined how native herpetofauna of the Cross Timbers in Oklahoma, USA, were influenced by vegetation types derived from combinations of herbicide applications and prescribed burning. Brush management treatments consisted of tebuthiuron $(\mathrm{N}-$ [5-(1,1-dimethylethyl)-1,3,4-thiazol-2-y-1]-N,N'-dimethylurea)only, tebuthiuron + fire, and untreated pastures of mature hardwood forest (no herbicide or fire). A total of 292 individuals representing 30 species was captured in 1994 and 1995 using timeconstrained searching and drift-fence arrays on 3 replicates of the 3 treatments. Relative total abundance and species richness of herpetofauna were similar on all 3 treatment types. However, differences were apparent by taxonomic group. In general, amphibians were most abundant in untreated and tebuthiuron-only pastures, lizards were most abundant on the untreated pastures, and snakes were most abundant on pastures treated with tebuthiuron + fire. Maintenance of a mosaic of habitats in the Cross Timbers may enhance diversity of the native herpetofauna.

Key Words: reptiles, amphibians, brush management, tebuthiuron, prescribed burning, Cross Timbers, Oklahoma.

The Cross Timbers is a western extension of the oak-hickory ecoregion and contains about 19 million ha of upland hardwood forest and tallgrass prairie in the central United States (Garrison et al. 1977, Soil Conserv. Serv. 1981). Livestock production in these oak-dominated rangelands is relatively limited because of low production of herbaceous forage (Scifres 1980). Brush management can increase production of herbaceous forage by selectively removing woody overstory species; this benefits livestock production (Scifres and Mutz 1978, Stritzke 1980, McCollum et al. 1987) and economic returns (Bernardo and Engle 1990, Bernardo et al. 1992).

There are no published studies that directly address effects of brush management on native herpetofauna, but a few studies from the western United States have revealed that abundances of lizards and snakes were reduced in areas that were either grazed by livestock or modified by humans (Busack and Bury 1974, Berry 1978, Jones 1981, 1988, Szaro et al. 1985, Bock et al. 1990). Our research in the Cross Timbers of central Oklahoma

The study was funded by the Departments of Zoology and Plant and Soil Sciences, Oklahoma State University, and the Oklahoma Cooperative Fish and Wildlife Research Unit (Okla. Dep. Wildl. Conserv., Okla. State Univ., U.S. Geol. Surv. Biol. Resour. Div., and Wildl. Manage. Inst., cooperating). We gratefully acknowledge the suggestions from the late G. L. Kirkland, Jr. This is a journal article of the Oklahoma Agricultural Experiment Station.

Manuscript accepted 30 May 1999.

\section{Resumen}

Examinamos como la herpetofauna nativa de los Cross Timbers de Okla., USA, fue influenciada por los tipos de vegetación derivados de combinaciones de tratamientos de herbicida y quemas prescritas. Los tratamientos de manejo de mata fueron tebuthiuron (N-[5-(1,1-dimethylethyl)-1, 3, 4-thiazol-2-y-1]-N, $N^{\prime}$-dimethylurea)-sólo, tebuthiuron + quema, y pastizales no tratados de bosque caducifolio maduro (no herbicida ni quema). Un total de 292 individuos representantes de 30 especies fueron capturados en 1994 y 1995 por medio de búsquedas de tiemporestringido y matrices de cercas de desvío en tres réplicas de los tres tratamientos. La abundancia relativa total y la riqueza de las especies de la herpetofauna fueron parecidas en los tres tipos de tratamiento. Sin embargo, se vieron diferencias por grupo taxonómico. Por lo general, los anfibios fueron más abundantes en los pastizales no tratados y los de tebuthiuron-sólo, las lagartijas fueron más abundantes en los pastizales no tratados, y las culebras fueron más abundantes en los pastizales tratados de tebuthiuron + quema. El mantenimiento de un mosaico de hábitat en los Cross Timbers puede fomentar la diversidad de la herpetofauna nativa.

showed that modification of this habitat with herbicides and fire can have both deleterious and favorable effects on native biota. Generally, eastern cottontail rabbits (Sylvilagus floridanusLochmiller et al. 1991, 1995), cotton rats (Sigmodon hispidus tex ianus-McMurry et al. 1994), and white-tailed deer (Odocoileus virginianus-Soper et al. 1993a, 1993b, Leslie et al. 1996) responded positively to annual burning as part of the brush management prescription. Conversely, occurrence and numbers of some avian species [e.g., Louisiana waterthrush (Seiurus motacil la), tufted titmouse (Parus bicolor)] were impacted negatively by habitat alterations associated with brush control (Schultz et al. 1992a, 1992b).

Landowners likely will continue to convert the Cross Timbers into grasslands (Boren et al. 1996), so it is important to understand effects of such conversion on wildlife populations. Our objective was to determine effects of derived habitat types resulting from brush management with herbicide and fire on populations of reptiles and amphibians in the Cross Timbers.

\section{Study Area and Methods}

We conducted our study on the Cross Timbers Experimental Range (CTER), located about $12 \mathrm{~km}$ southwest of Stillwater, Okla. ( $36^{\circ} 02^{\prime} 40^{\prime \prime}$ to $36^{\circ} 04^{\prime} 20^{\prime \prime} \mathrm{N}, 97^{\circ} 09^{\prime} 30^{\prime \prime}$ to $\left.97^{\circ} 11^{\prime} 39^{\prime \prime} \mathrm{W}\right)$. The 
CTER is a 648-ha research facility that lies near the western edge of the Cross Timbers ecoregion (Kuchler 1964). Upland forest of the CTER is dominated by post oak (Quercus stellata Wangenh.) and blackjack oak (Q. marilandica Muenchh.) in the overstory, interspersed with a mosaic of tallgrass prairie (Ewing et al. 1984). The understory is predominantly eastern redcedar (Juniperus virginiana L.), American elm (Ulmus americana L.), redbud (Cercis canadensis L.), poison ivy (Rhus radicans L.), and rough-leaf dogwood (Cornus drummondii Meyer). The predominant herbaceous ground cover is little bluestem [Andropogon scoparius (Michx.) Nash], but rosette panicgrass (Panicum oligosanthes Schultes), indiangrass [Sorghastrum nutans (L.) Nash], and western ragweed (Ambrosia psilostachya D.C.) occur in varying amounts throughout the CTER. Bottomland forest is restricted to intermittent stream drainages that transect the study area (Ewing et al. 1984).

The CTER was established in 1983 to evaluate responses of livestock and vegetation to various brush management techniques. It was divided into 20, 32.4-ha $(0.41 \times 0.79 \mathrm{~km})$ fenced experimental pastures that represented 4 replicates of 5 treatments comprising 2 herbicides and prescribed burning. Herbicide + fire treatments were burned annually for 3 years starting in 1985 and then on a 3-year rotation starting in 1990. Both herbicides were effective, although pastures treated with tebuthiuron (N-[5-(1,1-dimethylethyl)1,3,4-thiadiazol-2-yl]-N,N'-dimethylurea) resulted in the greatest tree kill of 52-99\% (Stritzke et al. 1987) and increased herbaceous production (Engle et al. 1991, Stritzke et al. 1991). Untreated habitats had a dense woody canopy, little herbaceous cover, and moderate amounts of woody understory (Engle et al. 1991, Stritzke et al. 1991). Treatments with fire had reduced cover of eastern redcedar (Stritzke et al. 1991), although other woody species were not greatly reduced by fire alone.

All experimental pastures were grazed by beef cows in 1984 and by yearling beef cattle in summer in 1985 and after. Stocking was adjusted annually on individual pastures on the basis of the residue of previous year's end-of-season herbage and expected forage production during the following year with the goal of $50 \%$ utilization of annual forage production (Stritzke et al. 1991).

In 1994 and 1995, we evaluated herpetofaunal communities on 3 of the 5 experimental treatments: (1) soil-applied tebuthiuron herbicide applied at $2 \mathrm{~kg}$ a.i. $\mathrm{ha}^{-1}$ in March 1983; (2) tebuthiuron + fire in spring; and (3) untreated (no herbicide or burning). We chose those treatments because they represented the maximal range of habitats available on the CTER relative to overstory cover and composition of the vegetation (Ewing et al. 1984). Untreated pastures were mature upland oak forest (Fig. 1a); tebuthiuron + fire treatments were open, park-like prairie with a scattering of eastern redcedar (Fig. 1b); and the tebuthiuron-only treatments were a mixed-brush type dominated by eastern redcedar (Engle et al. 1991, Stritzke et al. 1991; Fig. 1c)a derived habitat that was structurally and compositionally similar to dense stands of eastern redcedar that now occur on former prairies and hardwood forests through the south-central Great Plains due to fire supression. Production of grasses and forbs in 1994 and 1995 averaged $20 \mathrm{~kg} / \mathrm{ha}$ in the untreated pastures, 680 $\mathrm{kg} / \mathrm{ha}$ in the tebuthiuron-treated pastures, and $1,250 \mathrm{~kg} / \mathrm{ha}$ in the tebuthiuron + fire pastures (Engle, unpublished data). Canopy cover of woody plants in the upland forests was greatest in the untreated pastures and least in the tebuthiruon + fire pastures (Stritzke et al. 1991; Fig. 1). Woody vegetation in the treated pastures was less spatially homogenous than in the untreated pastures and understory production and composition reflected that variability (Fig. 1). Three of the 4 replicates of each of the 3 selected treatments ( 9 pastures) were chosen at random prior to sampling for reptiles and amphibians. Sampling was conducted only on those areas of experimental pastures that were upland forest prior to herbicide application.

Herpetofauna were sampled monthly from mid-May through early October, 1994, and late-March through early October, 1995. Two capture techniques were used to assess abundances of reptiles and amphibians. During the sampling period in 1994 , we performed time-constrained, search-and-seizure techniques

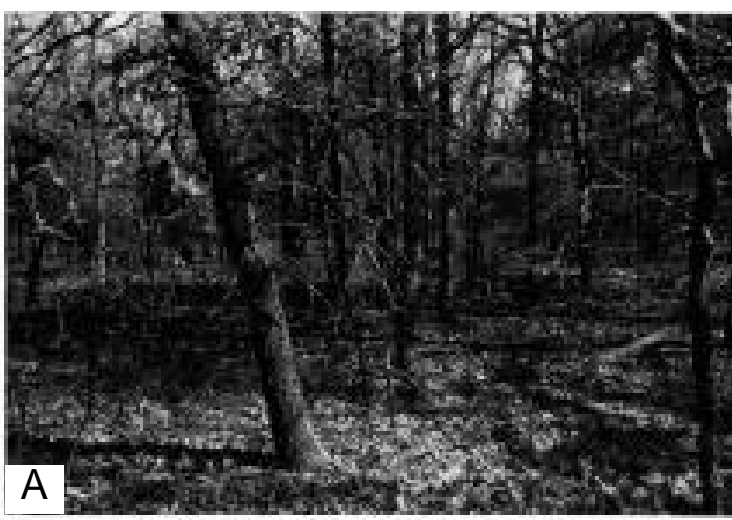

Fig. 1. Habitats in which herpetofauna were studied at the Cross Timbers Experimental Range resulting from the following treatments: a) untreated (no herbicide or fire), b) tebuthiuron + fire, and c) tebuthiuron only.

(Scott 1994). For sampling in 1995, we used both time-constrained searches and drift-fence arrays with funnel traps. Use of drift-fence arrays is a standard effective method of sampling reptiles and amphibians (Scott 1994). Use of standardized drift fences, in combination with searchand-seizure techniques, to assess relative abundance and species richness of reptiles and amphibians facilitates comparisons of experimental units (Enge and Marion 1986, Jones 1986, Bury and Corn 1987). Time-constrained searching allowed counting of species not readily caught in drift-fence arrays or funnel traps (Bury and Corn 1987, Scott 1994).

One drift-fence array was installed on each of the 9 pastures. Each array consist- 
ed of 3, 15.2-m x 30.5-cm lengths of galvanized metal flashing emanating from a central point and radiating out at $120^{\circ}$ angles. One edge of the flashing was buried about $6 \mathrm{~cm}$ below the ground surface, and the fence was stabilized on both sides with $2.5-\mathrm{x} 60-\mathrm{cm}$ wooden stakes placed near the ends and at 5-m intervals. We buried a 19.0-1 plastic drop can flush with the soil surface at the center of the array and at the end of each arm (Campbell and Christman 1982, Vogt and Hine 1982, Corn 1994). When drift fences were not in use, we placed lids on drop cans to prevent entry of animals. To reduce mortality during trapping sessions, lids were propped $10-12 \mathrm{~cm}$ above the drop can to provide shade and ventilation. To avoid confounding treatment effects, drift-fences were placed $\geq 100 \mathrm{~m}$ from treatment boundaries and $\geq 200 \mathrm{~m}$ from permanent water sources. We also placed one double-ended funnel trap constructed of aluminum window screening on each side of each array arm ( $n=6$ funnel traps per array). Funnel traps were $66 \mathrm{~cm}$ long and $16 \mathrm{~cm}$ in diameter with an inside funnel opening of $7 \mathrm{~cm}$ in diameter and were primarily intended for the capture of snakes. Thin rubberized floor mats were cut $30 \mathrm{~cm} \mathrm{x} 45 \mathrm{~cm}$ and were placed over the center of these traps to provide captured animals shelter from the weather. Traps were unbaited, which is standard for herpetofaunal studies.

Monthly drift-fence sampling periods in 1995 lasted 10 days. We checked arrays every second or third day during cool weather (daily high temperature $<25^{\circ} \mathrm{C}$ ) and every other day during hot weather (daily high temperature $>25^{\circ} \mathrm{C}$ ). Captured animals were identified to species, permanently marked by toe or scale clipping, and released at the point of capture. Recaptures were rare and were not included in data tabulations. Time-constrained searching was conducted in 1994 and 1995; each replicate received about 3.5 person-hours of active searching in 1994 and 2.5 person-hours in 1995 . Random encounters and opportunistic observations of reptiles and amphibians also were recorded during monitoring periods if they occurred $\geq 100 \mathrm{~m}$ from pasture boundaries and $\geq 200 \mathrm{~m}$ from permanent water.

Herpetofaunal taxonomic groups were not lumped together because of their differential responses to habitat structure based on their physiological and behavioral capabilities (Jones 1986). Because our data were not normally distributed and sample sizes of some species were small, we used chi-square analyses (SAS 1985) to assess frequencies of captures among treatments by taxonomic group (amphibian and reptile; the latter subdivided into turtle, lizard, and snake) and pooled data across the 3 pasture replicates in each treatment to maximize sample size. We used Kruskal-Wallis tests to evaluate treatment effects on individual species (Anderson et al. 1991). Significance was set at $\mathrm{P} \leq 0.10$.

\section{Results and Discussion}

We captured 292 animals representing 30 species during 2 years of study (Table 1). Thirty-six individuals of 16 species were documented during 32 hours of timeconstrained searching in 1994 (1.1 captures per person-hour). Time-constrained searching during the 1995 season yielded 48 captures of 14 species during 21.5 hours of active searching (2.2 captures per person-hour). The 9 drift-fence arrays and associated funnel traps produced 199 captures during 60 nights of effort (540 arraynights) between late March and early October, 1995 (0.4 captures per arraynight). Nine additional individuals were recorded as chance encounters in 1995.

Herpetofaunal abundance (summed over all 3 replicates) was greatest in untreated pastures $(n=110)$, less in tebuthiuron + fire pastures (95), and least in tebuthiurononly pastures (87) (Table 1). Species richness (summed over all 3 replicates) was similar among pastures: tebuthiuron + fire (22), tebuthiuron-only pastures (21), and untreated pastures (20). Of 30 species, 3 each were unique to untreated pastures and pastures treated with tebuthiuron + fire, and 2 species were found exclusively on tebuthiuron-only pastures (Table 1). Considering individual species, only numbers of the 5-lined skink (Eumeces fascia tus) varied among treatments, being more common on untreated pastures (KruskalWallis $\mathrm{W}=5.45,2 \mathrm{df}, \mathrm{P}=0.07)$.

Numbers of captures of reptiles and amphibians differed among treatments (Table 1). Both taxonomic groups were about equally common on untreated pastures, but amphibians were least common on pastures with tebuthiuron + fire, and reptiles were least common on tebuthiuron-only pastures. Reptile taxa (snakes, turtles, and lizards) also differed significantly among treatments (Table 1). Lizards were more abundant on untreated pastures and were less abundant on tebuthiuron-only plots. Snakes were most abundant in pastures treated with tebuthiuron + fire. Turtles were captured too infrequently for definitive conclusions about their habitat associations.

Amphibians were most abundant on untreated and tebuthiuron-only pastures. They were less common on the most open park-like pastures created with tebuthiuron + fire. Those open pastures were exposed to more insolation and were likely drier, which are conditions generally unfavorable for amphibians. Reptiles, like amphibians, were common on untreated pastures but were more abundant on tebuthiuron + fire pastures than on the dense mixed-brush pastures created by tebuthiuron-only. For the most part, reptiles tolerate drier conditions and bask more than amphibians. Nevertheless, reptile taxa were not uniform in their habitat affiliations. Lizards were least common on the brushiest pastures and were most common on untreated pastures. Skinks, a subgroup of lizards, were most common in untreated pastures, followed by tebuthiuron + fire, and then tebuthiuron-only $\left(\mathrm{X}^{2}\right.$ $=24.00,2 \mathrm{df}, \mathrm{P}<0.01)$. Snakes were most common in open park-like pastures and least so in untreated pastures. Prairie snakes such as the eastern yellowbelly racer (Coluber constrictor) were found exclusively on tebuthiuron + fire treatments. Rough earth snakes (Virginia striatula) also were most abundant on the prairie-like pastures that were treated with either tebuthiuron or tebuthiuron + fire.

Our results indicate that modification of the Cross Timbers with tebuthiuron-only has a negative effect on reptiles in general and lizards in particular. The tebuthiurononly treatment created the least heterogeneous habitats on the CTER and, 10 years post-treatment, was virtually an homogenous forest of eastern redcedar (J. F. Stritzke, pers. comm.), with little structural diversity. Changes in structural heterogeneity due to heavy grazing can reduce abundance and diversity of lizards (Jones 1981). Nevertheless, 2 species of snakes [speckled kingsnake (Lampropeltis getulus) and flathead snake (Tantilla gra cilis)] occurred exclusively on the tebuthiuron-only treatment, although both were represented by a single capture.

We could not analyze the effect of cattle grazing because all the experimental plots were grazed at similar intensity. Other research similar to ours focused on the direct effect of livestock grazing, which in most cases was negative for reptiles and amphibians (Reynolds 1979, Ballinger and Jones 1985, Bock et al. 1990, Fleischner 1994). 
Table 1. Numbers of captures of amphibians and reptiles on untreated and experimental pastures treated with tebuthiuron-only and tebuthiuron + fire at the Cross Timbers Experimental Range, Oklahoma, 1994-1995.

\begin{tabular}{|c|c|c|c|c|c|}
\hline \multirow[b]{2}{*}{ Category } & \multirow[b]{2}{*}{ Common name } & \multirow[b]{2}{*}{ Scientific name } & \multicolumn{3}{|c|}{ Treatments } \\
\hline & & & $\begin{array}{l}\text { Tebuthiuron- } \\
\text { only }\end{array}$ & $\begin{array}{l}\text { Tebuthiuron } \\
+ \text { fire }\end{array}$ & Control \\
\hline \multirow[t]{8}{*}{ Frogs/toads } & American toad & Bufo americanus & 6 & 6 & 19 \\
\hline & Cricket frog & Acris crepitans & 5 & 2 & 7 \\
\hline & Spotted chorus frog & Pseudacris clarkii & 0 & 1 & 1 \\
\hline & Strecker's chorus frog & Pseudacris streckeri & 1 & 0 & 1 \\
\hline & Great Plains & & & & \\
\hline & narrowmouth toad & Gastrophryne olivacea & 7 & 9 & 6 \\
\hline & Bullfrog & Rana catesbeiana & 2 & 4 & 1 \\
\hline & Southern leopard frog & Rana utricularia & 30 & 16 & 21 \\
\hline Salamanders & Smallmouth salamander & Ambystoma texanum & 0 & 3 & 0 \\
\hline $\begin{array}{l}\text { Total number of } \\
\text { amphibians }(\%)^{1}\end{array}$ & & & $51(35.2)$ & $38(26.2)$ & $56(38.6)$ \\
\hline \multirow[t]{3}{*}{ Turtles } & Red-eared slider & Trachemys scripta & 0 & 0 & 1 \\
\hline & Eastern box turtle & Terrapene carolina & 3 & 1 & 3 \\
\hline & Ornate box turtle & Terrapene ornata & 1 & 1 & 0 \\
\hline $\begin{array}{l}\text { Total number of } \\
\text { turtles }(\%)^{2}\end{array}$ & & & $4(40.0)$ & $2(20.0)$ & $4(40.0)$ \\
\hline \multirow[t]{6}{*}{ Lizards } & Slender glass lizard & Ophisaurus attenuatus & 1 & 1 & 0 \\
\hline & Northern prairie lizard & Sceloporus undulatus & 3 & 7 & 3 \\
\hline & Five-lined skink & Eumeces fasciatus & 2 & 7 & 26 \\
\hline & Great Plains skink & Eumeces obsoletus & 0 & 0 & 1 \\
\hline & Ground skink & Scincella lateralis & 7 & 8 & 12 \\
\hline & Six-lined racerunner & Cnemidophorus sexlineatus & 5 & 6 & 0 \\
\hline \multicolumn{6}{|l|}{ Total number of } \\
\hline lizards $(\%)^{2}$ & & & $18(20.2)$ & $29(32.6)$ & $42(47.2)$ \\
\hline \multirow[t]{13}{*}{ Snakes } & Eastern yellowbelly racer & Coluber constrictor & 0 & 4 & 0 \\
\hline & Ringneck snake & Diadophis punctatus & 0 & 2 & 1 \\
\hline & Eastern hognose snake & Heterodon platyrhinos & 1 & 0 & 1 \\
\hline & Speckled kingsnake & Lampropeltis getula & 1 & 0 & 0 \\
\hline & Coachwhip & Masticophis flagellum & 2 & 2 & 1 \\
\hline & Rough green snake & Opheodrys aestivus & 0 & 1 & 1 \\
\hline & Brown snake & Storeria dekayi & 1 & 1 & 0 \\
\hline & Flathead snake & Tantilla gracilis & 1 & 0 & 0 \\
\hline & Western ribbon snake & Thamnophis proximus & 1 & 3 & 0 \\
\hline & Rough earth snake & Virginia striatula & 6 & 12 & 2 \\
\hline & Smooth earth snake & Virginia valeriae & 0 & 1 & 0 \\
\hline & Copperhead & Agkistrodon contortrix & 0 & 0 & 1 \\
\hline & Timber rattlesnake & Crotalus horridus & 1 & 0 & 1 \\
\hline $\begin{array}{l}\text { Total number of } \\
\text { snakes }(\%)^{2}\end{array}$ & & & $14(29.2)$ & $26(54.2)$ & $8(16.7)$ \\
\hline $\begin{array}{l}\text { Total number of } \\
\text { reptiles }(\%)^{1}\end{array}$ & & & $36(24.5)$ & $57(38.8)$ & $54(36.7)$ \\
\hline $\begin{array}{l}\text { Total number } \\
\text { of captures }\end{array}$ & & & 87 & 95 & 110 \\
\hline $\begin{array}{l}\text { Total number } \\
\text { of species }\end{array}$ & & & 21 & 22 & 20 \\
\hline
\end{tabular}

\section{Management Implications}

Herbicides and prescribed fire are common range management tools, and we expect to see more rangeland of the Cross Timbers modified in this manner in the future (Boren et al. 1996). Our results suggest that the Cross Timbers can be man- aged for both cattle and wildlife by providing a mosaic of habitat types (Leslie et al. 1996) with applications of herbicide and prescribed fire in a spatially diverse pattern leaving some areas with unmodified mature upland forest. Application of tebuthiuron followed by prescribed burning is the most profitable practice for managing hardwood forests of the Cross
Timbers for cattle grazing (Bernardo and Engle 1990, Bernardo et al. 1992). Applying herbicide and burning treatments in a mosaic can increase carrying capacity of livestock and white-tailed deer and the profitability of livestock and lease hunting under multiple-use objectives in the Cross Timbers (Bernardo et al. 1992). The application scale for herbicide and 
burning treatments to optimize habitat for livestock and game species likely would be larger than the scale required for herpetofauna. Spot treatments, generally considered by rangeland managers as illadvised because they lead to overuse by grazing animals, perhaps could be used to enhance herpetofauna habitat under carefully controlled livestock grazing.

No single habitat, derived or not, is universally beneficial to herpetofauna or other wildlife. Herbicide application without fire does not benefit most reptiles, whereas herbicide with fire appears to negatively affect most amphibians. Complete removal of mature oak forest would alter species composition of amphibians and reptiles, and it might cause disappearance of some woodland species [e.g., skinks, (Eumeces spp.) and the copperhead (Agkistrodon contortrix)]. On a broader scale, native prairies in the south-central Great Plains that are now dominated by eastern redcedar due to decades of fire suppression likely have a less rich herpetofauna compared with more structurally diverse habitats, but even those areas appear to provide important habitat for some species.

\section{Literature Cited}

Anderson, D.R., D.J. Sweeney, and T.A. Williams. 1991. Introduction to statistics: concepts and applications. West Publishing Co., St. Paul, Minn.

Ballinger, R.E. and S.M. Jones. 1985. Ecological disturbance in a sandhills prairie: impact and importance to a lizard community on Arapaho prairie in western Nebraska. Prairie Nat. 17:91-100.

Bernardo, D.J. and D.M. Engle. 1990. The effect of manager risk attitudes on range improvement decisions. J. Range Manage. 42:242-249.

Bernardo, D.J., D.M. Engle, R.L. Lochmiller, and F.T. McCollum. 1992. Optimum vegetation management under multiple use objectives in the Cross Timbers. J. Range Manage. 45:462-467.

Berry, K.H. 1978. Livestock grazing and the desert tortoise. Trans. North Amer. Wildl. Nat. Resour. Conf. 43:505-519.

Bock, C.E., H.M. Smith, and J.H. Bock. 1990. The effect of livestock grazing upon abundance of the lizard, Sceloporus scalaris, in southeastern Arizona. J. Herpetol. 24:445-446.

Boren, J.C., D. M. Engle, M.S. Gregory, R.E. Masters, T.G. Bidwell, and V.A. Mast. 1996. Landscape structure and change in a hardwood forest-tallgrass prairie ecotone. J. Range Manage. 50:244-249.

Bury, R.B. and P.S. Corn. 1987. Evaluation of pitfall trapping in northwestern forests: trap arrays with drift fences. J. Wildl. Manage. 51:112-118.
Busack, S.D. and R.B. Bury. 1974. Some effects of off-road vehicles and sheep grazing on lizard populations in the Mojave Desert. Biol. Conserv. 6:179-183.

Campbell, H.W. and S.P. Christman. 1982. Field techniques for herpetofaunal community analysis, p. 193-200. In: N.J. Scott (ed.). Herpetological communities. U.S. Fish and Wildl. Serv. Wildl. Res. Rep. 13.

Corn, P.S. 1994. Straight-line drift fences and pitfall traps, p. 109-117. In: W.R. Heyer, M.A. Donnelly, R.W. McDiarmid, L.C. Hayek, and M.S. Foster (eds.). Measuring and monitoring biological diversity. Standard methods for amphibians. Smithsonian Institution Press, Washington, D.C.

Enge, K.M. and W.R. Marion. 1986. Effects of clearcutting and site preparation on herpetofauna of a north Florida flatwoods. For. Ecol. Manage. 14:177-192.

Engle, D.M., J.F. Stritzke, and F.T. McCollum. 1991. Vegetation management in the cross timbers: response of understory vegetation to herbicides and bruning. Weed Tech. 5:406-410.

Ewing, J.H., J.F. Stritzke and J. Kulbeth. 1984. Vegetation of the Cross Timbers Experimental Range, Payne County, Oklahoma. Oklahoma Agr. Exp. Sta. Res. Rep. P-586.

Fleischner, T.L. 1994. Ecological costs of livestock grazing in western North America. Conserv. Biol. 8:629-644.

Garrison, G.A., A.J. Bjugstad, D.A. Duncan, M.E. Lewis, and D.R. Smith. 1977. Vegetation and environment features of forest amd range ecosystems. U. S. For. Serv. Agr. Handb. No. 475.

Jones, K.B. 1981. Effects of grazing on lizard abundance and diversity in western Arizona. Southwest. Nat. 26:107-115.

Jones, K.B. 1986. Amphibians and reptiles, p. 267-290. In: A.Y. Cooperrider, R.J. Boyd, and H.R. Stuart (eds.). Inventory and monitoring of wildlife habitat. U.S. Dept. Interior, Bur. Land Manage., Denver, Colo.

Jones, K.B. 1988. Comparison of herpetofaunas of a natural and altered riparian ecosystem, $\mathrm{p}$. 222-227. In: R.C. Szaro, K.E. Severson, and D.R. Patton (eds.). Management of amphibians, reptiles, and small mammals in North America. U.S. For. Serv. Gen. Tech. Rep. RM-166.

Kuchler, A.W. 1964. Potential natural vegetation of the conterminous United States. Amer. Geogr. Soc. Spec. Publ. 36. New York, N.Y.

Leslie, D.M., Jr., R.B. Soper, R.L. Lochmiller, and D.M. Engle. 1996. Habitat use by white-tailed deer on cross timbers rangeland following brush management. J. Range Manage. 49:401-406.

Lochmiller, R.L., J.F. Boggs, S.T. McMurry, D.M. Leslie, Jr., and D.M. Engle. 1991. Response of cottontail rabbit populations to herbicide and fire applications on cross timbers rangeland. J. Range Manage. 44:150-155.

Lochmiller, R.L., D.G. Peitz, S.T. McMurry, D.M. Leslie, Jr., and D.M. Engle. 1995. Alterations in condition of cottontail rabbits (Sylvilagus floridanus) on rangelands following brush management. J. Range Manage. 48:232-239.

McCollum, F.T., D.M. Engle, and J.F. Stritzke. 1987. Brush management on the Cross Timbers Experimental Range: III. Carrying capacity and steer performance. Okla. Agr. Exp. Sta. Res. Rep. 110-113.
McMurry, S.T., R.L. Lochmiller, J.F. Boggs, D.M. Leslie, Jr., and D.M. Engle. 1994. Demographic profiles of populations of cotton rats in a continuum of habitat types. J. Mammal. 75:50-59.

Reynolds, T.D. 1979. Responses of reptile populations to different land management practices on the Idaho National Engineering Laboratory Site. Great Basin Nat. 39:255-262.

SAS. 1985. Procedure's guide. Stat. Analysis Sys., Inc., Cary, N.C.

Schulz, C.A., D.M. Leslie, Jr., R.L. Lochmiller, and D.M. Engle. 1992a. Herbicide effects on cross timbers breeding birds. J. Range Manage. 45:407-411.

Schulz, C.A., D.M. Leslie, Jr., R.L. Lochmiller, and D.M. Engle. 1992b. Autumn and winter bird communities on herbicide-treated cross timbers in Oklahoma. Amer. Midl. Nat. 127:215-223.

Scifres, C.J. 1980. Brush management: principles and practices for Texas and the southwest. Texas A\&M Press, College Station, Tex. 360 p.

Scifres, C.J. and J.L. Mutz. 1978. Herbaceous vegetation changes following applications of tebuthiuron for brush control. J. Range Manage. 31:375-378.

Scott, N.J. 1994. Complete species inventories, p. 78-84. In: W.R. Heyer, M.A. Donnelly, R.W. McDiarmid, L.C. Hayek, and M.S. Foster (eds.). Measuring and monitoring biological diversity. Standard methods for amphibians. Smithsonian Institution Press, Washington, D.C.

Soil Conservation Service. 1981. Land resource regions and major land areas of the United States. Soil Conserv. Serv. Handb. No. 296.

Soper, R.B., R.L. Lochmiller, D.M. Leslie, Jr., and D.M. Engle. 1993a. Nutritional quality of browse after brush management on cross timbers rangeland. J. Ranage Manage. 46:399-410.

Soper, R.B., R.L. Lochmiller, D.M. Leslie, Jr., and D.M. Engle. 1993b. Condition and diet quality of white-tailed deer in response to vegetation management in central Oklahoma. Proc. Okla. Acad. Sci. 73:53-61.

Stritzke, J.F. 1980. Effect of tebuthiuron on herbage production in tallgrass prairies. Southern Weed Sci. Proc. 33:114.

Stritzke, J.F., D.M. Engle, and F.T. McCollum. 1987. Brush management on the Cross Timbers Experimental Range. I. Brush problems and responses to herbicides. Oklahoma Agr. Exp. Sta. Res. Rep. MP-119:99-102.

Stritzke, J.F., D.M. Engle, and F.T. McCollum. 1991. Vegetation management in the Cross Timbers: response of woody species to herbicides and burning. Weed Tech. 5:400-405.

Szaro, R.C., S.C. Belfit, J.K. Aitkin, and J.N. Rinne. 1985. Impact of grazing on a riparian garter snake, p. 359-363. In: R.R. Johnson, C.D. Ziebell, D.R. Patton, P.F. Ffolliott, and F.H. Hamre (eds.). Riparian ecosystems and their management: Reconciling conflicting issues. U.S. For. Serv. Gen. Tech. Rep. RM-120.

Vogt, R.C. and R.L. Hine. 1982. Evaluation of techniques for assessment of amphibian and reptile populations in Wisconsin, p. 201-217 In: N.J. Scott (ed.). Herpetological communities. U.S.Fish and Wildl. Serv. Wildl. Res. Rep. 13. 